SAND96-8003 • UC-402

Unlimited Release

- $\quad$ Printed January 1996

\title{
Pollution Prevention Opportunity Assessment for the Protective Forces
}

\author{
H. M. Torres
}

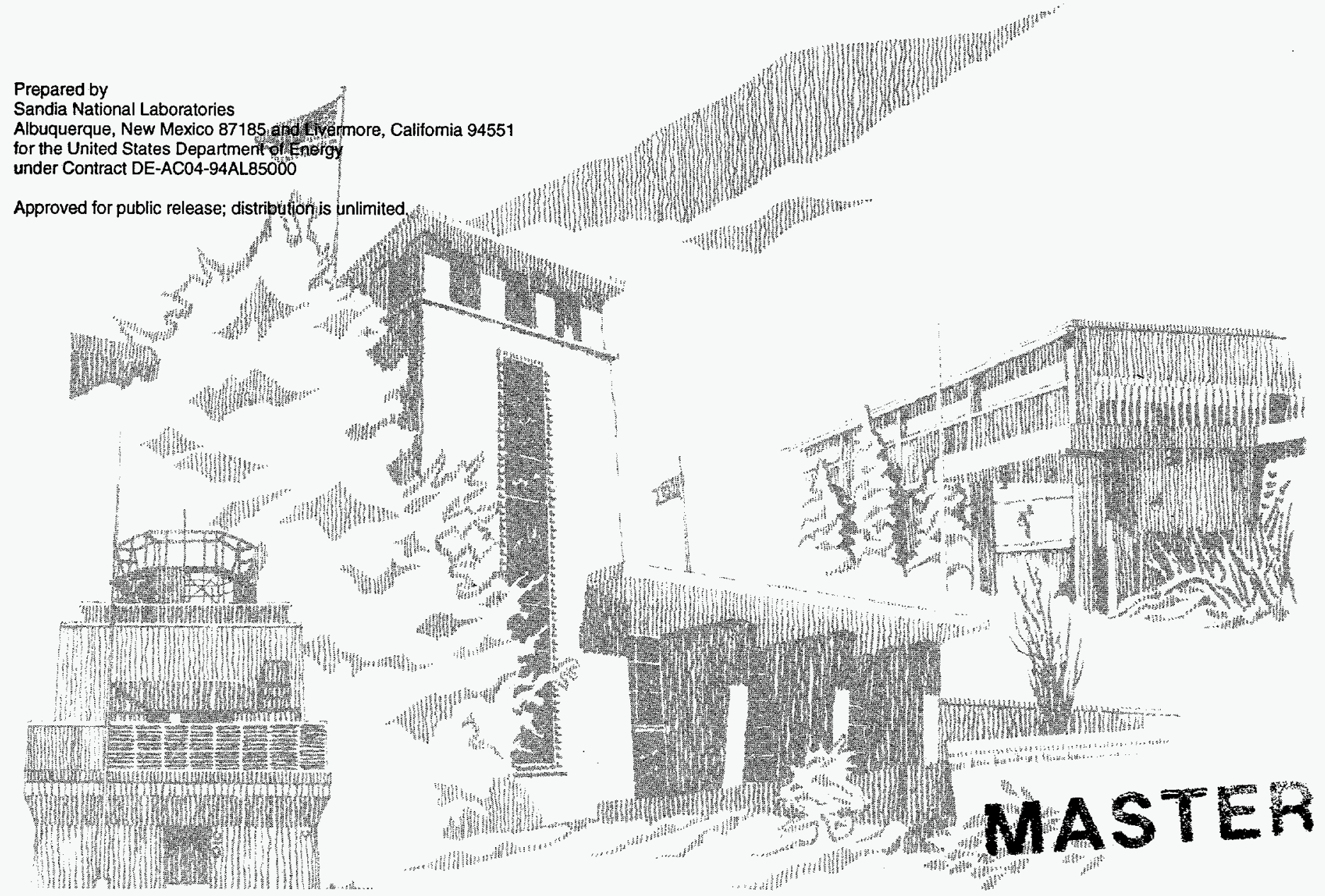


Issued by Sandia National Laboratories, operated for the United States Department of Energy by Sandia Corporation.

NOTICE: This report was prepared as an account of work sponsored by an agency of the United States Government. Neither the United States Government nor any agency thereof, nor any of their employees, nor any of the contractors, subcontractors, or their employees, makes any warranty, express or implied, or assumes any legal liability or responsibility for the accuracy, completeness, or usefulness of any information, apparatus, product, or process disclosed, or represents that its use would not infringe privately owned rights. Reference herein to any specific commercial product, process, or service by trade name, trademark, manufacturer, or otherwise, does not necessarily constitute or imply its endorsement, recommendation, or favoring by the United States Government, any agency thereof or any of their contractors or subconractors. The views and opinions expressed herein do not necessarily state or reflect those of the United States Government, any agency thereof or any of their contractors or subcontractors.

This report has been reproduced from the best available copy.

Available to DOE and DOE contractors from:

Office of Scientific and Technical Information

P. O. Box 62

Oak Ridge, TN 37831

Prices available from (615) 576-8401, FTS 626-8401

Available to the public from:

National Technical Information Service

U.S. Department of Commerce

5285 Port Royal Rd.

Springfield, VA 22161 


\section{DISCLAIMER}

Portions of this document may be illegible in electronic image products. Images are produced from the best available original document. 
SAND96-8003

Unlimited Release

Printed January 1966

\title{
POLLUTION PREVENTION OPPORTUNITY ASSESSMENT FOR THE PROTECTIVE FORCES
}

\author{
Hilary M. Torres \\ Environmental Protection Department \\ Sandia National Laboratories/California
}

\begin{abstract}
This pollution prevention opportunity assessment was conducted to evaluate the Protective Forces located at California Site. This assessment documents the processes, identifies the hazardous chemical waste streams generated by these processes, and recommends possible ways to minimize waste.
\end{abstract}




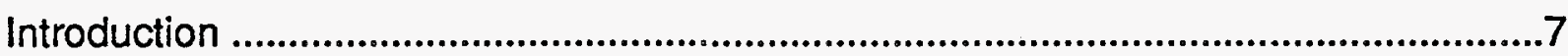

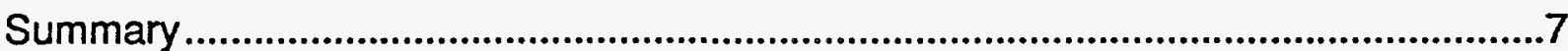

Pollution Prevention Opportunity Assessment .............................................................8

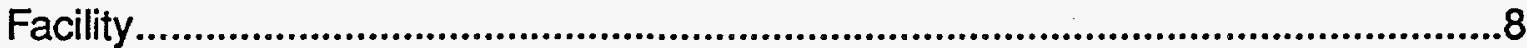

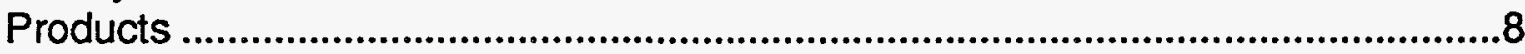

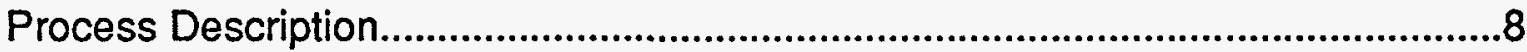

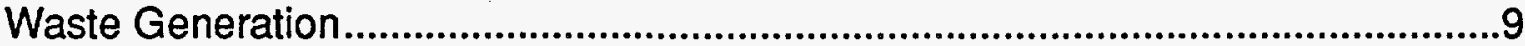

Waste Minimization Recommendations........................................................11

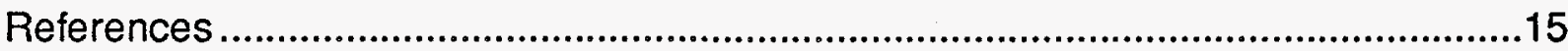

\section{APPENDICES}

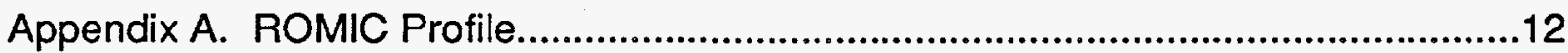

\section{ILLUSTRATIONS AND TABLES}

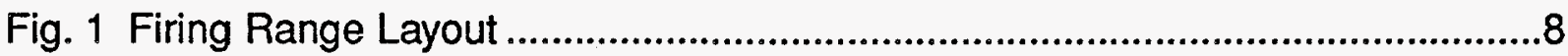

Fig. 2 Process Flow Diagram for Protective Forces...................................................

Fig. 3 Hazardous Waste Generation Summary .........................................................11

Table 1 Hazardous Waste Generation Summary ..................................................10 


\section{POLLUTION PREVENTION OPPORTUNITY ASSESSMENT FOR THE PROTECTIVE FORCES}

\section{Introduction}

Department of Energy (DOE) orders 5400.1 and 5400.3 mandate the development of a waste minimization program. ${ }^{1,2}$ The program's goals are to:

- reduce volumes of hazardous wastes and toxicity,

- implement a system of tracking and reporting improvements, and

- devise a method for performing tasks.

To satisfy the requirements of this program, Sandia conducts pollution prevention opportunity assessments (PPOAs) to identify waste-generating processes. The information collected from a PPOA then is used to identify waste minimization opportunities.

This PPOA was conducted for the Protective Forces, according to the Pollution Prevention Opportunity Assessment Plan for SNL/California. ${ }^{3}$

\section{Summary}

The primary mission for Protective Forces (Organization 8811) is to prevent the compromise of classified matters. Protective Services personnel provide guard and protection services for the materials, facilities, property and personnel at SNL/CA. The Firing Range, located at the southern most boundary of SNL/CA for approximately 20 years, and parts of Buildings 912 and 964 make up the area for which the Protective Forces are responsible. The major hazardous waste streams routinely generated by the Protective Forces are lead contaminated water and contaminated wipes. Protective Forces personnel contaminate the water by using city water to wash their hands after target practice. The contaminated water goes off site for recycling. Personnel contaminate the disposable wipes with solvent during weapons cleaning. Weapons cleaning takes place at both Buildings 964, Room 005, and the Firing Range. In the future, a large, one-time disposal of native soil contaminated with lead from this area will be required.

Sandia fills bags with native soil to trap bullets and to avoid bullet dispersal on the surrounding grounds during target practice. Frequent use makes the bags shred and lose soil. The soil fallen out of the bags will need remediation.

Protective Forces personnel regularly look for opportunities to minimize hazardous waste. The following are several steps taken by Protective Forces:

- DOE is researching different types of ammunition. Some ammunitions do not contain lead.

- Spent casing from the Firing Range are sent off site for recycling as scrap brass.

- Officers are required to wear gloves during weapons cleaning to reduce the risk of dermal exposure to solvents. 
- After October 1995, Protective Forces personnel will no longer have an auxiliary firearm.

\section{Pollution Prevention Opportunity Assessment}

\section{Facility}

Protective Forces.

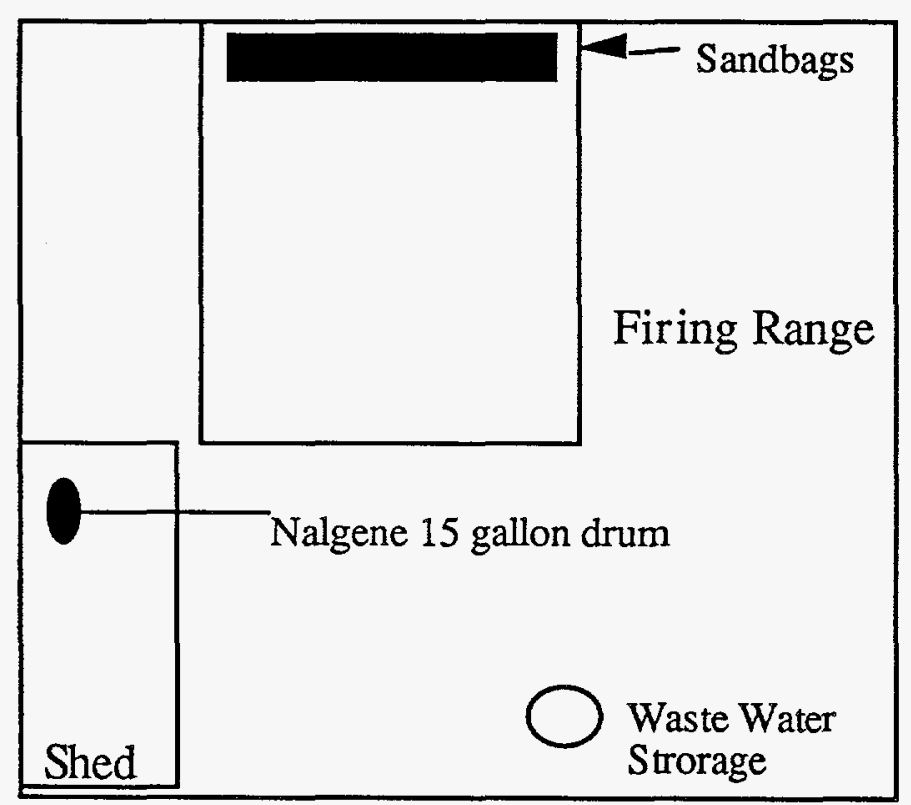

Figure 1. Firing Range Layout.

\section{Products}

The maintenance of a protective force here at SNL/CA.

\section{Process Description}

The Protective Forces provides SNL/CA protection of the grounds, facilities, and materials within the boundaries. Responsibilities also include security orientation and administration of assigned personnel as well as property and personnel contracted to SNL/CA. Certain items are provided by DOE for Protective Forces. The DOE issues weapons, ammunition, and other specialized items of equipment. 


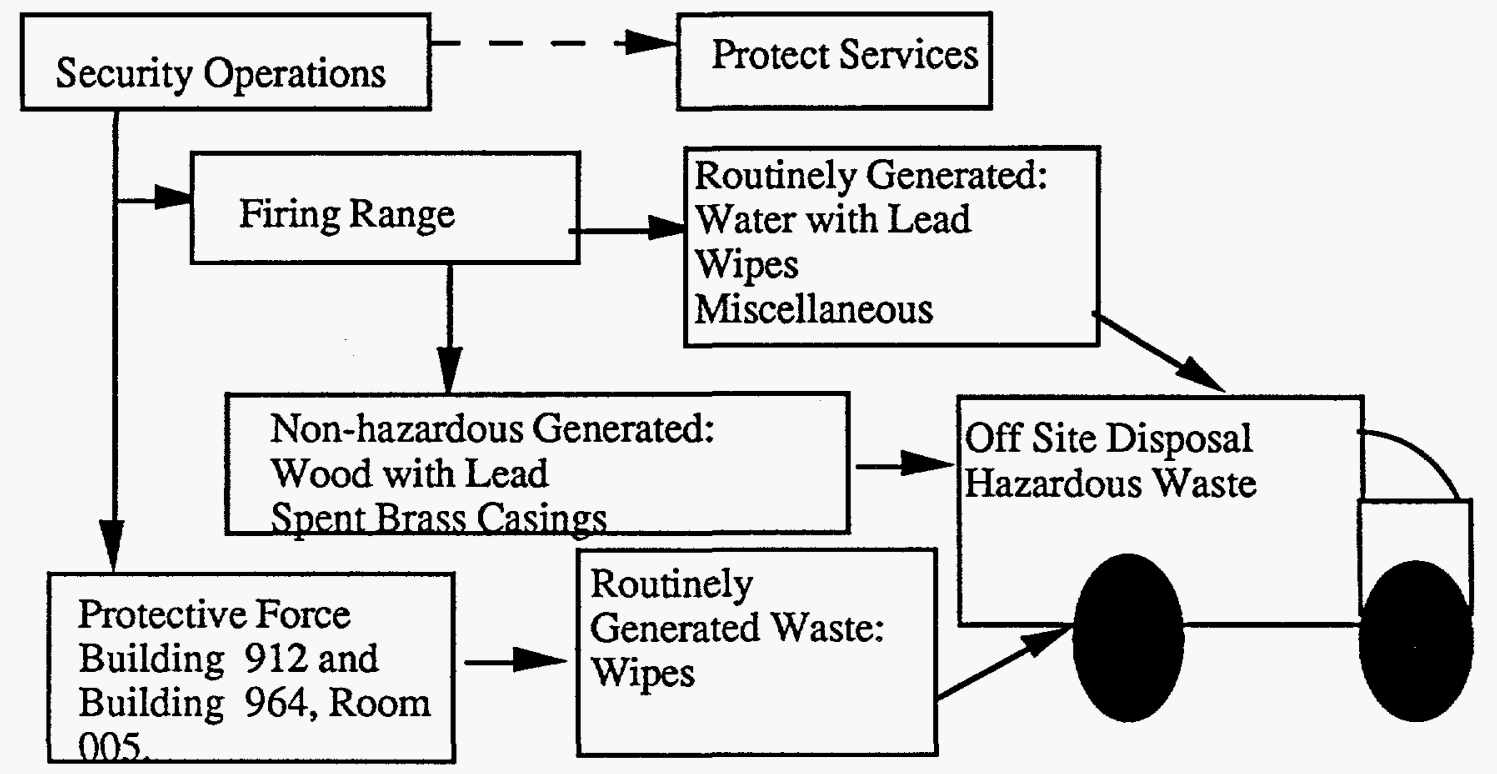

Figure 2. Process Flow for Protective Forces.

\section{Waste Generation}

The primary hazardous waste streams generated by Security Operation Department are:

- Water containing Lead

- Contaminated wipes

Because of the lead in ammunition that the Protective Force uses, the Firing Range Shed houses an area for personnel to wash their hands. City water is stored in a 15 gallon Nalgene drum with a spout that drains into a basin. Personnel wash their hands as the water pours from the drum. The water then drains from the bottom of the basin, down a tube and is collected in a 5 gallon carboy. Waste Management personnel empty the water into a 55 gallon drum, which is stored outside. Once the 55 gallon drum is filled, Waste Management personnel arrange to have the drum transported off site for disposal.

Analysis of the wastewater has consistently shown levels above what is considered acceptable by the City of Livermore Water Reclamation Department. Therefore, the wastewater from the Firing Range cannot be released to the sewer. Sandia sends it off site as hazardous waste for recycling (See Appendix A). Sandia publishes an analysis of the wastewater from the Firing Range annually in a DOE required document that is titled, Site Environmental Report.

Protective Services personnel use various types of solvents during weapons cleaning. To eliminate dermal exposure, personnel wear 100\% Nitrile gloves, as required, and use disposable wipes during this process. Sandia sends the contaminated wipes and gloves off site as hazardous waste. 
As a backstop, Sandia uses soil native to this area in sandbags at the Firing Ranges. Protective Services personnel place the sandbags behind the targets as a buffer and to collect stray bullets. In the past, after much use, the soil from the shredded sandbags is rebaged and reused. However, the soil is high in lead content. In the future, personnel will dispose of the soil as hazardous waste and not reuse it.

After October of 1995, the Security Officers no longer had an auxiliary weapon available. The Department modified the auxiliary weapons (MP5 rifles) from an automatic to semiautomatic weapon. The only fire arms Protective Services personnel carry are handguns in a holster.

Table 1. illustrates the two major waste stream for both 1993 and 1994 water with lead and contaminated wipes. Slight increases in the volume of water with lead in 1994 was due to increased use of the Firing Range.

Table 1. Waste Generation Summary

\begin{tabular}{|r|c|c|}
\hline Waste Stream ID & $\begin{array}{c}\text { Waste generated (kg) } \\
1993\end{array}$ & $\begin{array}{c}\text { Waste generated (kg) } \\
1994\end{array}$ \\
\hline Water with Lead & 128 & 184 \\
\hline Rags/Wipes & 62 & 47 \\
\hline Aerosol Cans & $\bullet$ & 0 \\
\hline Batteries & $*$ & 90 \\
\hline Miscellaneous & 0 & 30 \\
\hline \hline Empty Containers & 1 & 1 \\
\hline Total & 191 & 352 \\
\hline
\end{tabular}

*Aerosol cans and batteries were counted and not weighed during 1993. 


\section{Waste Generation Summary}

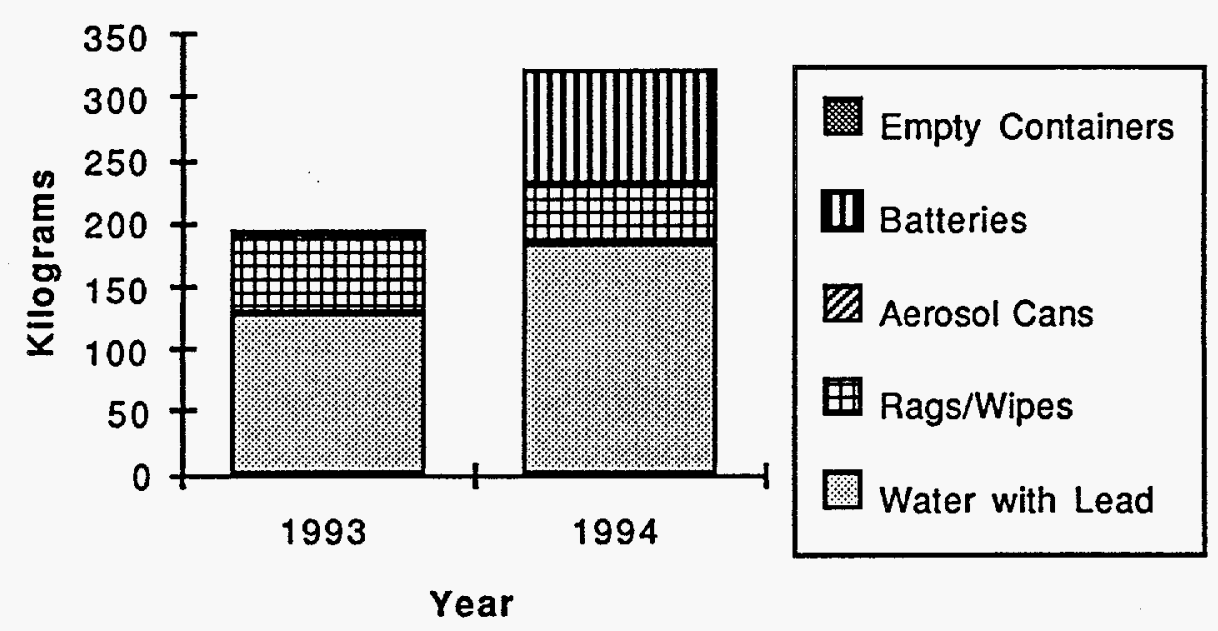

Figure 3. Hazardous Waste Generation Summary.

\section{Recommendations}

- At some point in the future, Sandia will require a large disposal of native soil contaminated with lead. The Firing Range has been in use for 20 years. Over this period of time, Sandia has made upgrades; however, Sandia has not remediated soil from the site. Further sampling and data analysis is needed to evaluate the lead content of the soil.

- A recommendation was made to replace disposable contaminated wipes with a laundry service. However, further evaluation of this option is needed. The cost of a laundry service may exceed the cost of disposable contaminated wipes as hazardous waste. When weapons are cleaned, an extremely clean wipe is needed. Laundered rags may not meet the needs of the Protective Forces personnel.

- The DOE authorizes the type of ammunition used at Sandia, California. Currently, frangible ammunition that is lead free and breaks apart on contact is under investigation as a possible ammunition for DOE sites. Using this ammunition would significantly reduce those hazardous waste streams that contain lead. If frangible ammunition were approved by DOE, hand washing at the firing range would no longer be necessary. This would eliminate the generation of water with lead as a waste stream. 


\section{APPENDIX A}

\section{ROMIC PROFILE}

HAZARDOUS WASTE

STATE ANO FEDERAL LAW PROHIBITS IMPROPER DISPOSAL. IF FOUND, CONTACT IHE NEAREST POLICE, OR PUBLIC SAFETY AUTHORITY, OR THE U.S. ENVIRONMENTAL PROTECTION AGENCY OR THE CALIFORNIA DEPARTMENT OF HEALTH SERVICES

GENERATOR INFORMATION:

NAME: SANDIA NATIONAL LABORATORIES

ADORESS: 7011 EAST AVENUE

PHONE: 510 294-2002

CITY: LIVERMORE STATE: CA ZIP: $94551-0969$

EPA IMANIFEST

ID NO./ DOCUMENT NO. CAD289002923 /

EPA CA ACCUMULATION

WASTE NO. D008 WASTE NO. 132 START DATE

CONTENTS, COMPOSITION: A.WATER W/ IRACE LEAD CONTAMINATION

PHYSICAL STATE: | hazARDOUS PROPERTIES: - FLAMMABLE — TOXIC - SOLID X LIQUID I _ CORROSIVE _ REACTIVITY - OTHER:

D.O.T. PROPER SHIPPING NAME HAZARDOUS WASTE, LIQUID, N.O.S.

9 NA3082 PGIII

(LEAD)

HANDLE WITH CARE! 
PROPIIE SHEET No. B-C19087 ; Statug: Accepted by East Palo Alto Pacility

ROMIC ENVIRORMENTAL TECR.

2081 Bay Road, East Palo Alto, CA 94303 (800) Rasic-4-U FAX: (425) 462-2311

6760 W. All180n Rd., Chandler, AZ 85226 (602) 796-1040 FAX: (602) 796-7944

A. TRATOR INFORMATION

SANDIX NATIONAL IABORATORIES

TO11 EAST AVENUE

LIVERYORE, CA 94551.0969

EPACA HN IDH: CAD289002923

Contact: KEVIN LLOYD

Phone: $510294-2002$

Industrial src code: None Ilsted

B. CUSTOMER INFORMATION : NO ADDITIONAL INFORMATION

2. TRANSPORTER INFORMATION

ROMIC ENVIRONAENTAT, TECH.

EPA ID\#: CAD009452657

CONtACt: CUSTOAER SERVICE

Hauler ID\#(8): State - CA number - 0160

Phone: $800 \quad 766-4248$

D. WASTE STREAM INFORMATION

Name of Naste: WATER CONTAM $\mathrm{k} /$ LEAD

Process Generating waste (Be Specific): EMPLOYER CLEAN HAND W/ LAVA SOAP AT GUN RANGE

E. HAZARDOUS PROPERTIES

US EPA Hazardous Waste Code (s): D008

CA State Hazardous kaste Code: 132

F. OTHER COMPORENTS

Cyanides, Sulfides, Amines, PCBs, and/or Phenolles are Nor Present.

Chronium VI: 0 ppon

3. APPROVED PROPER SHTPPING DESCRIPTION BASED URON AVATIABIE INFORMATION (New Info from hN-181 on left 1f appIicable)

HAZARDOUS MASTE, LIQUTD, N.O.S.

$\operatorname{ka3082}$ PGIII

$$
\text { AD) }
$$

Wote: Lowest $R Q$ for individual constituenta in or characteristics of this vaste is I pounds. Generator ia

responsible for determining if the designation of RQ must be added to shipping description based upon quantity in container.

1. PKYSICAL CHARACTERISTICS

COlOr: CLR BROWT

Free Ifquids (t Volume): $100 \quad$ single Iayer

pH: - 7 Specific Gravity: $1.1-1.2$ Flash polnt: NONE

I. CHENICAI COMPOSITION

A. WATER W/ TRACE LEAD CORTAMIRATION

J. TOTAL METALS (ppmal

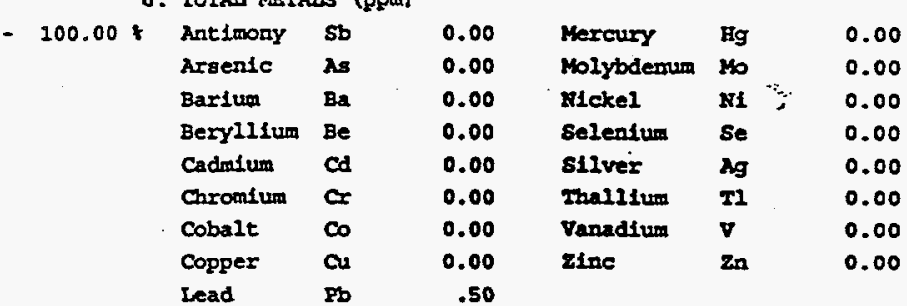

ACCEPT/REJECT DATE: 12-OCt-1993

Recertification required two years from this Date

Authorized Romic Signature:

or 
UNIFORM HAZAROOUS WASTE MANIFEST
1. Generator's US EPA ID No. CA0289002923
3. Generator's Name and Mail ing Address SANDIA NATIONAL LABORATORIES 7011 EAST AVENUE

LIVERMORE, CA 94551-0969

4. Generator's Phone: $510294-2002$

5. Iransporter 1 Company Name RONIC ENVIRONMENTAL TECH.

7. Transporter 2 Company Name

7. Transporter 2 Conpany Wame

9. Designated facility Name and Site Address ROMIC ENVIRONMENTAL TECH.

2081 Bay Road

East Palo Alto, CA 94303-1316

Contact: KEVIN LLOYD

A. State Manifest Document Number

B. State Generator's I0

HA HQ \#\#-\#\#\# Or HY HQ H-\#

6. US EPA ID Number CAD009452657

C. State Transporter's 10

D. Transporter's Phone: 800 766-4248

F. State Transporter's 10

F. Transporter's Phone:

8. US EPA IO MUDER

G. State Facility's 10

CA D 00.9452657

H. Facility's Phone

CADO09452657

11. US OOT Description (Including Proper Shipping Name, Hazard Class, and ID Number) (415) $324-1638$

a. HAZARDOUS WASTE, LIQUID, H.O.S.

9 NA3082 PGIII

(LEAD)

I. Waste No.

State 132

- EPA 0008

EPA/Other SEE BOX 15

J. Additional Descriptions for Materials Listed Above

A.WATER H/ TRACE LEAD CONTAMINATION $\quad-100 \%$

15. Special Handling Instructions and Additional Information Line \# Profile\# DOT ERG \# EPA/Other Waste Code(s) C19087. 31 


\section{References}

Clark, Tommy, 1995, Sandia Protective Forces, Personnel Communication with H. M. Torres.

Verges, Christopher, 1995, Sandia Protective Forces, Personnel Communication with H. M. Torres.

Sandia National Laboratories/California, Site Environmental Report for 1994.

Pollution Prevention Opportunity Assessment Plan for Sandia National Laboratories/California, PD457712, March, 1995.

U.S. DOE, Sandia National Laboratories/California, Environmental Protection Hazardous Waste Container Log, (1993/94).

Penguin Industrial Inc., Material Safety Data Sheets (MSDS), Hoppe's \#9 Nitro Powder Solvent, (August 3, 1992).

California Toxicity Regulation, California Code of Regulations, Title 22, Section $66261.24(2)(\mathrm{A})$.

RCRA D List, Hazardous Waste Codes, 40 CFR, Part 261, Table 1.

Sandia National Laboratories/California, Statement of Work for Protective Force, November 1, 1990. 


\section{UNLIMITED RELEASE}

\section{INITIAL DISTRIBUTION}

U. S. Department of Energy (2)

Albuquerque Operations Office

Attn.: J. L. Arellano, KAO

J. E. Orban, WMD

P. O. Box 5400

Albuquerque, NM 87115

MS1305, R. Davis, Org. 7576

MS1305, M. Walsh, Org. 7576

MS9001, T. Hunter, Org. 8000

Attn.: E. E. Ives, 5200

J. B. Wright, 2200

M. E. John, 8100

W. J. McLean, 8300

L. A. Hiles, 8800

P. N. Smith, 8500

T. M. Dyer, 8700

R. C. Wayne, 8400

D. L. Crawford, 8900

MS9052, S. F. Rice, Org. 8361

MS9406, B. Haroldsen, Org. 8412

MS9408, B. G. Brown, Org. 8414

MS9021, K. W. Gordon, Org. 8815

MS9041, K. K. Shepodd, Org. 8814

MS9221, T. Larson, Org. 8418

MS9222, H. M. Torres, Org. 8402

MS9222, N. M. Phillips, Org. 8418 (15)

MS9222, S. J. Raubfogel, Org. 8418

MS9222, G. Varozza, Org. 8418

MS9021, Technical Communications Dept., 8815, for OSTI (10)

MS9021, Technical Communications Dept., 8815/Technical Library, 13414

MS0899, Technical Library, 13414 (4)

MS9018, Central Technical Files, Org. 8950-2 (3) 